INTERNATIONAL JOURNAL OF MULTIDISCIPLINARY RESEARCH AND ANALySis

ISSN(print): 2643-9840, ISSN(online): 2643-9875

Volume 04 Issue 04 April 2021

DOI: 10.47191/ijmra/v4-i4-05, Impact Factor: 6.072

Page No.- 395-398

\title{
A Preliminary Checklists of Birds for the Fura and Furagosa Wildlife Community Based Conservation Area, in Mirab-Abaya District, Gamo Zone, Southern Ethiopia
}

\author{
Amare Gibru ${ }^{1}$, Yihew Biru ${ }^{2}$, Zelalem Temesgen ${ }^{3}$, Kibebew Hunde ${ }^{4}$ \\ 1,2,3,4 Ethiopian Biodiversity Institute \\ P.O. Box- 30726, Addis Ababa, Ethiopia
}

\begin{abstract}
The field visit was conducted during February 2021 with the aim to prepare a primary bird checklist in Fura and Furagosa community based wildlife conservation areas. Transect walk data collection method was employed. The record of bird list was presented in a descriptive statics. Thus, a total of 37 bird species were recorded during the survey time. Of the species recorded, 25 species were residents, 10 species Palearctic migrants and 2 Intra-African migrants. The survey suggests that further systematic studies of biodiversity are needed.
\end{abstract}

KEY WORDS: Migratory bird, Ecotourism, Conservation.

\section{INTRODUCTION}

Ethiopia has a large variety of indigenous plant and animal species. As of (2014) Ethiopian biodiversity institute report, there were at least 284 species of mammals, 861 species of birds, 201 reptile species, 200 fish species, 63 amphibian species 1225 arthropod(324 butterfly) species and over 6,000 species of plants throughout the country. The birdlife in Ethiopia is exceptional in East Africa, high number of species recorded with high endemism. According to Leapage (2021), 873 species recorded from Ethiopian IBAs from which 19 species are endemic to the country. However, there is a distinct lack of adequate knowledge of avifauna assemblages and their distributions across different habitats (EWNHS 1996). Most of the biological resources particularly wildlife's are concentrated in protected areas (IUCN, 1994). However, Ethiopia efforts have increased in establishments of national parks, wildlife sanctuary and reserves to gain environmental and economic benefits but the value obtained from the protected areas is very low (Solomon \& Dereje, 2015). The lakes in the Great Rift Valley region abound with numerous species of birds, and wild animals are found in every region (Taylor and Tudorancea, 2002). From the common wildlife species like the leopard, cheetah, lion, civet, African bush elephant, bushpig, gazelle, antelope, ibex, kudu, dik- dik, oribi, reedbuck, Somali wild ass, Grévy's zebra, hyena, baboon, and numerous species of monkey are widely distributed in the rift (BirdLife International, 2021). Fura and Furagosa community based wildlife conservation area is part of the rift valley systems which the proposed community based conservation site comprises a distinctive habitat types and it is known for feeding and wintering grounds for many migratory birds.

Fura and Furagosa community based wildlife conservation area is found in Mirab Abaya that is one of the woredas in the Southern Nations, Nationalities, and Peoples' Region of Ethiopia, Part of the Gamo Zone. Mirab Abaya is bordered on the east and south by Lake Abaya which separates it from the Oromia Region on the east and Arba Minch Zuria on the south, on the west by Chencha, on the northwest by Borena, and on the north by the Wolayita Zone. It has an elevation of 1100 to $2900 \mathrm{~ms}$ above sea level \& average annual rainfall and temperature between $800-1600 \mathrm{ml}$ and $24-30{ }^{\circ} \mathrm{C}$, respectively (Nigussie and Alemayehu , 2013; Direslgne et al., 2016).

This community based wildlife area covers $25 \%$ of Abaya Lake and estimated over 5,691 ha area of land. The conservation area has around 11 unique islands and sticky mountains area and inhabits ample terrestrial and aquatic wildlife. Lake Abaya is part of the Main Ethiopian Rift is found in west side of this district town and east of the Guge Mountains range. The town of Arba Minch lies on its southwestern shore, and the southern shores are part of the Nechisar National Park. Just to the south is Lake 


\section{Preliminary Checklists of Birds for the Fura and Furagosa Wildlife Community Based Conservation Area, in Mirab-}

Abaya District, Gamo Zone, Southern Ethiopia

Chamo; Savanna, known for its wildlife and birdlife, surrounds the lake, which is also fished by local people. This Lake is supplied by a major drainage system; the tributaries are the Bilate River from the north, the Gidabo and Gelana rivers from the east, and the Hare, Amessa and Basso rivers from the west (Direslgne et al., 2016). Adjacent to the lake there is agricultural field (banana farm) which is used to for local farmers as income and supplied for local market for users. The woodland surrounded all the rest is shown unique and very attractive scenic view when the area is looked from top to downwards (Figure 1).

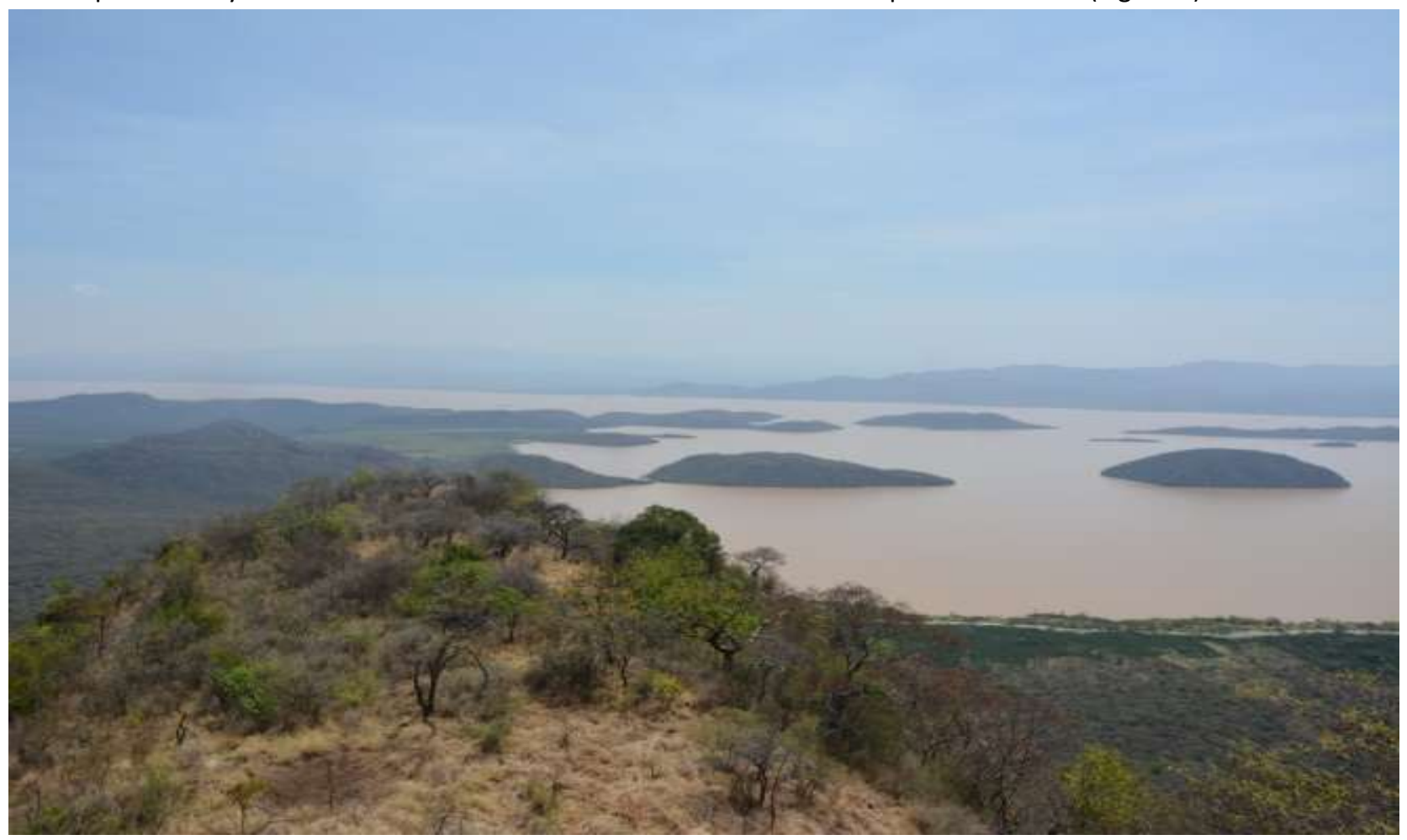

Figure 1. Photo view of the part of Fura and Furagosa community based wildlife conservation area.

We conducted a primary field survey of birds in February 2021. Birds were recorded in a transect walk for the open wetland habitats and Abaya lake shoreline. In the woodland and agricultural field areas, slow-moving vehicle were employed to count birds along the habitats by rounding the area following the road paths. Active bird recording was conducted in the morning and afternoon two times field visit for each habitats for around six hours in 100 to $300 \mathrm{~m}$ sighting distance. The period of observation for each field work varied, based on the habitat types. Observations were aided by binoculars and photographs were taken for further identification of inconspicuous species.

The species checklist during the survey is provided in Appendix 1. According to Birdlife international(2001),Aviceda cuculoides, Macheiramphus alcinus, Chelictinia riocourii, Gypaetus barbatus, Accipiter ovampensis, Francolinus levaillantii, Podica senegalensis, Schoutedenapus myoptilus, Coracina caesia and Serinus reichardi, Falco naumanni, Phoeniculus somaliensis, Lanius dorsalis, Cisticola bodessa, Mirafra albicauda, Myrmecocichla albifrons and Circus macrourus were recorded during their prior survey. Additional 37 bird species were recorded from the Fura and Furagosa community based wildlife conservation site during the six hours surveys (Appendix 1 ).

From the species recorded in the survey area, African pygmy Goose Nettapus auritus, Black-winged Stilt Himantopus himantopus, Greater Sand Plover Charadrius leschenaultia, Grey Heron Ardea cinerea, Hottentot Teal Spatula hottentota, Little Ringed Plover Charadrius dubius, Marsh Warbler Acrocephalus alustris, Pied Avocet Recurvirostra avosetta, White Stork Ciconia ciconia and White-winged Black Tern Childonias leucopetrus were Palaearctic Migrants. Intra-African Migrants like Abdim's stork Ciconia abdimii and Grey-headed Kingfisher Halcyon leucocephala were also recorded.

The area supports populations of two Highland Biome species Ruppell's Robin-chat Cossypha semirufa and Wattled Ibis Bostrychia Carunculata and one Somali-Masai biome species Ruppell's Weaver Ploceus.

The presence of high number of species and globally importance species in Fura and Furagosa community based wildlife conservation area makes it important as $\mathrm{CBC}$ and has potential as eco-tourism site. It is also suggested that further systematic studies are required to find inclusive species checklists. The existence of Nechisar national park and Arbaminch town in nearby 
Preliminary Checklists of Birds for the Fura and Furagosa Wildlife Community Based Conservation Area, in MirabAbaya District, Gamo Zone, Southern Ethiopia

the area are produces important site for ecotourism activities. Sound conservation systems should be given to conservation of this area for sustainable human use. Co-operating the local people to conserve the area as community based wildlife conservation area and proposing for ecotourism site from Gamo zone and local community empowerment and direct involvement in the conservation of the area are inspiring progress.

\section{ACKNOWLEDGEMENTS}

The field visit was financially supported by the Ethiopian biodiversity institute. Our especial thanks goes to Mr. Gambura Ganta at Gamo zone biodiversity case team leader for his accompanying us on field work.

\section{REFERENCES}

1) BirdLife International (2021) Important Bird Areas factsheet: Nechisar National Park and surroundings. Downloaded from http://www.birdlife.org on 22/03/2021.

2) Direslgne Misker, Begosew Misker and Gistane Ayele (2016). Households dietary diversity and associated factors in Mirab Abaya wereda Southern Ethiopia 2016; community based cross sectional study. Diversity and Equality in Health and Care 13(4): 293-296

3) Ethiopian Biodiversity Institute (EBI) (2014) Ethiopia's Fifth National Report to the Convention on Biological Diversity. Ethiopian Biodiversity Institute, Addis Ababa.

4) Ethiopian Wildlife and Natural History Society (EWNHS) (1996). Important Bird Areas of Ethiopia. Ethiopian Wildlife and Natural History Society, Addis Ababa. 300p.

5) IUCN,1994. Guidelines for Protected Area Management Categories. IUCN-The World Conservation Union, Gland.

6) Lepage D (2021). Avibase-Bird check lists of the World-Ethiopia. Available at: https://avibase.bsc-eoc.org/checklist.jsp?region=ET

7) Solomon Chanie \& Dereje Tesfaye (2015. Threats of biodiversity conservation and ecotourism activities in Nechsar National Park, Ethiopia. Int. J. Biodivers. Conserv.7 (2):130-139.

8) Taylor, W.D. and Tudorancea, C (2002). Ethiopian Rift Valley Lakes. Leiden: Backhuys Publishers

9) Zerihun Nigussie and Getachew Alemayehu (2013). Levels of household food insecurity in rural areas of Guraghe zone, Southern Ethiopia. Wudpecker Journals 2(1): 008-014.

Appendix 1. A Primary bird checklists of Fura and Furagosa community based wildlife conservation area in February 2021.

\begin{tabular}{llll}
\hline Species Name & Abaya lake shore & Wood-land & Farm-land \\
\hline Abdim's stork Ciconia abdimii & $\times$ & $\times$ \\
African Fish Eagle Haliaeetus vocifer & $\times$ & & \\
Africa Jacana Actophilomis africanus & $\times$ & $\times$ & $\times$ \\
African Grey Hornbill Lophoceros nasutus & & $\times$ & $\times$ \\
African Harrier-Hawk Polyboroides typus & & $\times$ & $\times$ \\
African Mourning Dove Streptopelia decipiens & $\times$ & $\times$ & \\
African pygmy Goose Nettapus auritus & & $\times$ & $\times$ \\
Black kite Milvus migrans & $\times$ & $\times$ \\
Black-winged Stilt Himantopus himantopus & & & \\
Blue-spotted Wood Dove Turtur afer & & $\times$ \\
Chestnut Sparrow Passer eminibey & $\times$ & $\times$ \\
Egyptian Goose Alopochen aegyptiacus & $\times$ & $\times$ \\
Goliath Heron Ardea goliath & $\times$ & $\times$ \\
Great Carmmorant Phalacrocorax carbo & $\times$ & $\times$ \\
Great Egret Egretta alba & $\times$ & $\times$ \\
Greater Blue-eared Starling Lamprotornis chalybaeus & & & \\
Grey headed Gull Larus cirrocephalu & $\times$ & & \\
Grey Heron Ardea cinerea & $\times$ & & \\
\hline
\end{tabular}


Preliminary Checklists of Birds for the Fura and Furagosa Wildlife Community Based Conservation Area, in MirabAbaya District, Gamo Zone, Southern Ethiopia

Grey-headed Kingfisher Halcyon leucocephala

Hadada ibis Bostrychia hagedash

Hammer kop Scopus umbretta

Hottentot Teal Spatula hottentota

Intermediate egret Egretta intermediary

Laughing Dove Streptopelia senegalensis

Lesser Jacana Microparra capensis

Lesser Swamp Warbler Acrocephalus gracilirostris

Little Egret Egretta garzetta

Little Ringed Plover Charadrius dubius

Little Weaver Ploceus luteolus

$\begin{array}{ll} & x \\ \times & x \\ x & \\ x & \end{array}$

Malachite Kingfisher Alcedo cristata

Marabou Stork Leptoptilos crumeniferus

Marsh Warbler Acrocephalus alustris

Mourning Collared-dove Streptopelia decipiens

Northern Carmine Bee-eater Merops nubicus

Pied Avocet Recurvirostra avosetta

Pied Kingfisher Ceryle Rudis

Red-billed Hornbill Tockus erythrorhynchus

Red-eyed Dove Streptopelia semitorquata

Ruppell's Long-tailed Starling Lamprotornis purpuropterus

Ruppell's Robin-chat Cossypha semirufa

Ruppell's Weaver Ploceus galbula

Sacred Ibis Threskiomis aethiopicus

Saddle-billed Stork Ephippiorhynchus negalensis

Silver-cheeked Hornbill Bycanistes brevis

Slender-billed Starling Onychognathus tenuirostris

Speckled mousebird Colius striatus

Spur-winged Plover/Lawping Vanellus spinosus

Wattled Ibis Bostrychia Carunculata

White Stork Ciconia ciconia

Whitebacked Duck Thalassomis leuconotus

White-winged Black Tern Childonias leucopetrus

$x \quad x$

Yellow -billed storck Mycteria ibis

$x$ indicates that the species present in the area but without $x$ the species absent in the above table. 